\title{
Formulasi Mutu Kurikulum Madrasah Unggulan Berbasis Pesantren di Jember
}

\author{
Arbain Nurdin ${ }^{*}$, Akhmad Munir² \\ 1'Institut Agama Islam Negeri Jember \\ 2 Institut Agama Islam Negeri Jember
}

Keywords:

Formulation, Quality, Madrasah Curriculum

Kata Kunci:

Formulasi, Mutu, Kurikulum Madrasah

*Correspondence Address: arbainnurdin@iain-jember.ac.id

\begin{abstract}
The importance of repositioning pesantren in responding to the times and demands of society, so inevitably pesantren must be able to take a role and carry out a constructive movement by formulating the boarding school education system by organizing quality formal institutions, one of which is by adopting a philosophy and quality improvement management approach by not adopting the whole. its philosophy that prioritizes business interests, which is generally widely applied in companies that pursue profit from the process of moral, intellectual, and spiritual empowerment so that they have mental personality maturity The purpose of this study was to describe the concept of mapping curriculum needs, curriculum formulation, and curriculum operationalization policies in Islamic Primary Schools based on Islamic schools, namely MTs Unggulan Al Qodiri 1 Jember and MTs Unggulan Nurul Islam 1 Jember. While the research approach is qualitative with a type of case study. The result of his research is that the superior Islamic boarding schools map the curriculum based on the vision and mission of the pesantren and the madrasah itself, then formulate the curriculum with several work programs and communicate each curriculum policy with the leadership of the pesantren foundation.
\end{abstract}

\begin{abstract}
Abstrak: Pentingnya reposisi pesantren dalam merespon perkembangan zaman dan tuntutan masyarakat, maka mau tidak mau pesantren harus mampu mengambil peran dan melakukan gerakan konstruktif dengan memformulasi sistem pendidikan pesantren dengan menyelenggarakan lembaga formal yang bermutu, salah satunya dengan mengadopsi filosofi dan pendekatan manajemen peningkatan mutu dengan tidak mengadopsi keseluruhan filosofinya yang mengutamakan kepentingan bisnis, yang pada umumnya banyak diterapkan di perusahaan yang mengejar keuntungan provit dari pada proses pemberdayaan moral, intelektual dan spiritual sehingga memiliki kematangan mental kepribadian. Tujuan Penelitian ini adalah untuk mendeskripsikan konsep pemetaan kebutuhan kurikulum, formulasi kurikulum serta kebijakan operasionalisasi kurikulum di Madrasah Unggulan Berbasis Pesantren yaitu di MTs Unggulan Al Qodiri 1 Jember dan MTs Unggulan Nurul Islam 1 Jember. Sedangkan pendekatan penelitian ini adalah kualitatif dengan jenis studi kasus. Hasil penelitiannya ialah Madrasah unggulan berbasis pesantren memetakan kurikulum berdasarkan visi misi pesantren dan madrasah itu sendiri, lalu memformulasi kurikulum dengan beberapa program kerja serta mengkomunikasikan setiap kebijakan kurikulum dengan pimpinan yayasan pesantren.
\end{abstract}




\section{PENDAHULUAN}

Pondok pesantren dari lahirnya, hingga di era global ini mempunyai daya tarik yang khas sebagai institusi pengembangan dan proses pendewasaan peserta didik, ditilik dari sisi kehidupan sehari-harinya, sistem dan metodenya, isi pendidikanya dan lain sebagainya, baik pondok pesantren yang masih bercorak tradisional (konvensional) maupun yang bercorak modern. Dengan maraknya pendidikan berlabel internasional, semakin menambah ketatnya persaingan mutu pendidikan, terlebih lagi di lingkungan pesantren. Persaingan ini tentu saja memposisikan pesantren agar tetap menjadi lembaga pendidikan yang dibutuhkan oleh masyarakat.

Menurut Azra di dalam bukunya yang berjudul Konteks Berteologi di Indonesia; pengalaman Islam menyatakan bahwa eksistensi pesantren sebagai lembaga pendidikan tradisional diyakini dalam catatan sejarah telah mampu berkontribusi penting bagi proses keberlangsungan ilmu-ilmu keislaman, menghasilkan generasi ulama, pemeliharaan ilmu, dan kebudayaan Islam, hingga pada proses terbentuknya dan menyebarnya masyarakat Muslim santri. Selanjutnya Suwendi menyatakan bahwa keberadaan pesantren secara makro telah berperan dalam memberikan penyadaran kepada masyarakat agar memiliki spirit idealisme, kapasitas intelektual, serta akhlak yang baik agar dapat terbentuknya karakter melalui proses yang berkelanjutan. ${ }^{1}$

Fenomena tersebut tentu saja dinilai sebagai bentuk perubahan

\footnotetext{
1 Siswanto Siswanto, "Desain Mutu Pendidikan Pesantren," KARSA: Jurnal Sosial dan Budaya Keislaman 23, no. 2 (2016): 259.

2 Marno, Islam: By Management and Leadership (Jakarta: Lintas Pustaka, 2007), 100.
}

pendidikan pesantren ke arah yang lebih modern. Sebagaimana pandangan Marno, bahwa perubahan pondok pesantren bisa dilihat dari munculnya lembaga/ sekolah-sekolah umum di lingkungan pondok pesantren, yang pada akhirnya pondok pesantren menjadi sub-sistem dari pendidikan Nasional. $^{2}$

Memperhatikan pentingnya reposisi pesantren dalam merespon perkembangan zaman dan tuntutan masyarakat, keberadaan pondok pesantren diharapkan mampu berperan serta dalam gerakan konstruktif untuk memformulasi sistem pendidikan pesantren dengan menyelenggarakan lembaga formal yang bermutu, salah satunya dengan mengadopsi filosofi dan pendekatan manajemen peningkatan mutu dengan tidak mengadopsi keseluruhan filosofinya yang mengutamakan kepentingan bisnis, yang pada umumnya banyak diterapkan di perusahaan yang mengejar keuntungan provit dari pada proses pemberdayaan moral, intelektual dan spiritual sehingga memiliki kematangan mental kepribadian.

Berdasarkan peran dan urgensinya pesantren dalam lingkungan masyarakat, memberikan kesempatan bagi pesantren untuk membuka diri dengan banyaknya fakta bahwa masyarakat masih perlu pendidikan yang unggul dalam konteks lembaga yang lahir dari pesantren dengan konsep modernnya sehingga dapat melahirkan lulusan yang punya dua kualitas baik itu pada aspek akademik dan akhlaknya. ${ }^{3}$

3 Mujtahid, "Pengembangan Madrasah Dan Sekolah Islam Unggulan," Jurnal el-Hikmah: Fakultas Tarbiyah UIN Malang IX, no. 1 (2011): 274-289. 
Menurut Sukardjo dan Kamaruddin bahwa pendidikan bermutu dapat di identifikasi dari aspek prestasi-prestasi siswa, proses pembelajaran, kompetensi lulusan dalam mengaplikasikan dan mengejawantahkan potensinya di tengah-tengah kehidupan masyarakat melalui daya berpikir kritis dan kemampuan dalam pemecahan masalah. Pendidikan bermutu dapat dikaji secara komprehensif, sehingga memberi gambaran secara utuh dan tidak terpecah-pecah. Seperti mutu pendidikan dalam ranah proses, hal ini dapat terlihat dari beragam aspek, contohnya pada kualitas seorang guru atau tenaga pengajar, adanya sarana dan prasana yang memadai serta lingkungan belajar yang mendukung terciptanya kurikulum pembelajaran yang baik. Faktor-faktor inilah yang akan berdampak kepada mutu pendidikan dan melahirkan lulusan yang bermutu dan bersaing guna baik di tingkat lokal maupun internasional. ${ }^{4}$

Fenomena hadirnya madrasah unggulan berbasis pesantren, adalah babak baru pesantren menggalang kebangkitan mutu dan bersinergi dengan perkembangan zaman, bukan semata-mata mengadopsi, namun tetap kokoh menjaga reputasi pesantren di tengah derasnya gelombang kompetisi sebagai konsekuensi perkembangan globalisasi. Pesantren mampu tampil dan menjadi bagian penting dalam mengembangkan pendidikan nasional melalui penyelenggaraan madrasah unggulan berbasis pesantren. Umumnya madrasah unggulan berkembang di daerah perkotaan yang mayoritas sudah dilabelisasi oleh Pemerintah sebagai madrasah Negeri yang mengembangkan keunggulan- keunggulan tertentu, kini pesantren sebagai madrasah swasta juga turut serta diapresiasi dan di dukung oleh pemerintah untuk mengembangkan potensi madrasahnya sesuai dengan kultur dan ekspektasi pesantren dan masyarakat pada umumnya.

Berdasarkan fakta objektif di atas, proses peningkatan mutu menjadi penting, dituntut para stakeholder pondok pesantren mampu melakukan terobosan dan gagasan kreatif dan kebijakan strategis dalam rangka peningkatan mutu madrasah unggulan berbasis pesantren, sehingga menjadikan madrasah sebagai institusi unggul, dapat melahirkan generasigenerasi yang memiliki keluasan ilmu, kematangan jiwa dan keluhuran akhlak, serta memiliki keterampilanketerampilan profesional yang akan menjawab tuntutan zaman dan kebutuhan masyarakat. Maka peneliti tertarik untuk meneliti tentang formulasi mutu kurikulum madrasah unggulan berbasis pesantren di Jember dan objek penelitiannya adalah MTs Unggulan Al Qadiri 1 Jember dan MTs Unggulan Nurul Islam 1 Jember.

\section{KAJIAN TEORI Mutu Kurikulum Madrasah Unggul}

Sekolah atau madrasah unggulan di lihat dari aspek kurikulum tentunya merujuk pada aturan dan kebijakan pendidikan nasional. Secara bertahap dilakukan melalui penyiapan dan penulisan materi ajar berbahasa Inggris, untuk Mata Pelajaran (MAPEL) umum dan berbahasa Arab untuk mata pelajaran PAI dan Bahasa Arab, khususnya pada jenjang MTs. Selain itu kurikulum diperkaya dengan berusaha mengadopsi kurikulum dari sekolah

\footnotetext{
4 Siswanto, "Desain Mutu Pendidikan Pesantren."
} 
pada negara maju. Keunggulan yang dapat dikembangkan adalah:

1. Sekolah dapat mengembangkan program seperti literasi di bidang alQur'an untuk tenaga pendidik dan peserta didik;

2. Sekolah mengembangkan program atau kegiatan dalam bidang karya tulis menulis ilmiah yang bertujuan untuk mengembangkan budaya literasi peserta didik;

3. Sekolah merumuskan standar pembelajaran berbasis teknologi atau pembelajaran online;

4. Sekolah membuat dan menetapkan standar implementasi bahasa asing dalam proses pembelajaran di Madrasah;

5. Sekolah menciptakan dan menyusun standar lingkungan dan budaya religius;

6. Sekolah mengadakan kegiatan ekstrakurikuler maupun intrakurikuler yang menunjang terbentukknya nilai-nilai karakter di dalam proses pembelajaran di madrasah;

7. Sekolah menetapkan standar kompetensi lulusan yang unggul diantaranya nilai akademik minimal 7,5. Menetapkan standar kemampuan dan kompetensi berbahasa asing untuk para tenaga pendidik dan peserta didik di madrasah, dan menetapkan standar pencapaian prestasi peserta didik di bidang non akademik. ${ }^{5}$

8. Proses pembelajaran yang dikembangkan haruslah interaktif dan memotivasi sehingga menjadikan materi yang diajarkan

5 SK Kakanwil Yogyakarta, "Lampiran Surat Keputusan Kepala Kantor Wilayah Kementerian Agama Provinsi Daerah Istimewa Yogyakarta No. 609B Tahun 2012 Tentang Rintisan Madrasah Unggulan, Petunjuk Teknis Penyelenggaraan Ratusan Madrasah Unggulan," 2012. dapat kontekstual dan relevan dengan perkembangan zaman peserta didik.

Secara umum, Kementerian Pendidikan dan Kebudayaan telah menetapkan kriteria yang dimaksud sekolah unggul sebagai berikut: 1). Input, atau seleksi penerimaan peserta didik baru dilaksanakan secara selektif sesuai standar yang ditetapkan; 2). Ada sarana prasarana di sekolah yang cukup dan baik untuk mendukung proses pembelajaran; 3). Lingkungan sekolah yang mendukung untuk belajar; 4). Kualifikasi guru dan karyawan yang ada di sekolah memenuhi standar yang ditetapkan oleh Undang-undang; 5). Ada kurikulum yang kontekstual dan dapat mengembangkan minat dan bakat peserta didik; 6). Waktu pembelajaran di sekolah unggul lebih panjang dibangingkan dengan sekolah lainnya; 7). Proses pemebelajaran bermutu; 8). Adanya tambahan materi pelajaran selain mata pelajaran yang sudah ditetapkan di dalam kurikulum nasional; 9). Menjadi sumber referensi bagi sekolah lain. ${ }^{6}$ Berbeda dengan madrasah model, secara umum persyaratan yang dikriteriakan sebagai berikut: 1) Memiliki manajemen madrasah yang baik; 2) memiliki sumber daya manusia yang kompenten; 3) Memiliki sarana prasarana pendidikan yang lengkap; 4) adanya sumber pemasukan atau bantuan pendidikan yang cukup baik; 5) Lulusan memiliki mutu dan unggul dibanding lulusan sekolah lainnya. ${ }^{7}$

6 Fa'uti Subhan, Membangun Sekolah Unggulan Dalam Sistem Pesantren (Surabaya: Alpha, 2006), 19.

${ }^{7}$ Fuad Fachruddin, "Madrasah Model: Indikator Obyektif Dan Operasionalnya," Jurnal Madrasah 3 (1998): 80. 
Berbagai kriteria tentang madrasah maupun sekolah yang unggul ataupun madrasah model tentunya merujuk pada Peraturan Pemerintah No. 19 tahun 2005 tentang Standar Nasional Pendidikan (SNP) sebagai kriteria minimal sistem pendidikan Indonesia. Standar pendidikan ini memiliki fungsi sebagai dasar dalam perencanaan, pelaksanaan, serta supervisi pendidikan untuk mewujudkan pendidikan nasional yang bermutu. Di dalam peraturan pemerintah No 19 tahun 2005 terdapat delapan standar yang dijadikan kriteria minimal madrasah atau sekolah, yang tediri: standar lulusan, standar isi, standar proses, standar pendidik dan tenaga kependidikan, standar sarana prasarana, standar pengelolaan, standar pembiayaan, dan standar penilaian pendidikan. ${ }^{8}$

$\begin{array}{ccc}\text { Proses } & \text { menjadikan madrasah } \\ \text { sebagai } & \text { madrasah } & \text { unggulan }\end{array}$
memerlukan beragam aspek dan indikator. Zayadi menyebutkan bahwa ada dua aspek yang menjadi indikator dijadikannya sebuah madrasah menjadi madrasah unggulan, yaitu aspek administratif dan ketenagaan. Pada aspek administratif madrasah unggulan harus memiliki jumlah rasio guru dengan peserta didik 1:25, adanya dokumentasi yang komprehensif pada setiap proses pendidikan dan perkembangan peserta didik. Sedangkan pada poin ketenagaan, madrasah ungggulan harus memiliki guru yang berkompeten seperti bergelar magister, kompeten di bidang bahasa asing, baik itu bahasa Inggris maupun bahasa Arab. Selanjutnya karyawan ataupun staf yang bekerja sebagai tenaga kependidikan juga

8 "Peraturan Pemerintah Nomor 19 Tahun 2005 Tentang Standar Nasional Pendidikan," 2005. berkompeten di bidangnya masingmasing. Lalu peserta didik yang berada di madrasah unggulan juga harus mampu memiliki beragam keterampilan dan prestasi baik itu di bidang akademik maupun non akademik. Kurikulum yang diimplementasikan pada madrasah unggulan adalah kurikulum yang berbasis konteks dan sesuai dengan perkembangan zaman, hal ini pun di dukung oleh sarana prasarana yang memadai dan lengkap demi menunjang dan mendukung lahirnya lulusan terbaik yang memiliki kompetensi sesuai kebutuhan masyarakat saat ini. ${ }^{9}$

Moedjiarto mengidentifikasi ada tiga model madrasah atau sekolah Islam yang bercirikhas unggulan: model pertama adalah madrasah atau sekolah Islam berbasis pada anak cerdas. Model madrasah ini sangat selektif pada proses penerimaan peserta didik baru, namun pada pelaksanaan pembelajaran tidak terlalu unggul sehingga lulusan dari madrasah ini cukup berhasil karena memang peserta didiknya adalah pilihan. Kedua, model madrasah atau sekolah Islam berbasis pada sarana prasana yang memadai. Model madrasah ini lebih menekankan pada aspek fisik bangunan yang megah dan komplit baik secara desain maupun isi dan kegunaannya. Dampak dari sarana yang megah ialah biaya pendidikan pun menjadi tinggi. Ketiga, model madrasah atau sekolah Islam berbasis pada iklim belajar. Model madrasah ini lebih menekankan kepada lingkungan belajar yang kondusif dan tertata dengan sistem yang ketat. Model madarasah ini juga menerima dan memproses siswa yang pada awal masuk dengan prestasi

9 Ahmad Zayadi, Desain Pengembangan Madrasah (Jakarta: Dirjen Kelembagaan Pendidikan Islam Depag, 2005), 57. 
rendah menjadi lulusan yang bermutu tinggi. ${ }^{10}$

Menurut pandangan pakar mutu, Philip Crosby, Edward Deming dan Joseph Juran, yang tergambarkan dalam konsep peningkatan mutu (Total quality manajemen), pada prinsipnya dalam meraih kualitas, maka komitmen harus dibangun dalam setiap diri, hal ini dikarenakan: pertama, kunci keberhasilan suatu program dapatlah ditentukan oleh mutu atau kualitas itu sendiri. Kedua, adanya komitmen dari setiap sumber daya manusia untuk mewujudkan mutu atau kualitas secara istiqamah. Ketiga, adanya sikap dari setiap diri untuk menjadikan mutu sebagai budaya organisasi. Keempat, adanya bimbingan, penyuluhan dan pelatihan untuk mewujudkan mutu organisasi. Kelima, adanya keikutsertaan seluruh elemen dan stakeholder di dalam organisasi untuk mewujudkan mutu dan kualitas yang terus menerus. ${ }^{11}$

\section{METODE}

Pada penelitian ini, pendekatan kualitatif deskriptif yang digunakan untuk mengumpulkan dan mendeskripsikan data-data lapangan atau lokasi/ tempat penelitian berupa catatan, dokumen, naskah hasil wawancara dan lainnya yang tidak berupa angka-angka. ${ }^{12}$ Jenis peneiltian menggunakan studi kasus, yaitu riset yang memfokuskan pada aspek kasuskasus kontemporer berdasarkan fakta lapangan dari berbagai sumber. ${ }^{13}$

\footnotetext{
10 Moedjiarto, Sekolah Unggul (Surabaya: Duta Graha Pustaka, 2002), 34.

11 Sallis Edward, Total Quality Management In Education, ed. AHmad Ali Riyadi (Jogjakarta: IRCiSoD, 2008), 25.

12 Lexy J Moleong, Metodologi Penelitian Kualitatif(Bandung: Remaja Rosdakarya, 2005),
} 6.
Tehnik pengumpulan data menggunakan tiga metode yaitu wawancara, observasi dan dokumentasi, kemudian dianalisa menggunakan model Miles, Huberman dan Saldana yakni kondensasi data, penyajian data dan penarikan kesimpulan. ${ }^{14}$

\section{HASIL DAN PEMBAHASAN \\ Konsep Pemetaan Kebutuhan Kurikulum di MTs Al-Qodiri Unggulan 1 Jember dan MTs Unggulan Nurul Islam 1 Jember}

Konsep pemetaan kebutuhan kurikulum di MTs Unggulan Al Qodiri 1 Jember dan MTs Unggulan Nurul Islam 1 Jember mendasarkan kepada visi, misi dan tujuan pondok pesantren serta visi dan misi madrasah, karena secara historis setiap pesantren punya dasar historis yang panjang dengan berbagai dinamika dan problematikanya yang dialami pengasuh termasuk juga bentuk keprihatiannya terhadap kondisi yang berkembang di lingkungan pesantren, perkembangan masyarakat, maupun perkembangan zaman.

MTs Unggulan al-Qodiri 1 Jember merumuskan kurikulum berdasarkan cita-cita pesantren yang tergambar didalam visi misi pesantren, sebagaimana hasil wawancara dengan Wakil Kepala MTs sebagai berikut:

Bahwa berdasarkan visi pesantren lalu oleh kami sebagai pemangku kebijakan di MTs Unggulan AlQodiri 1 Jember ini merumuskan visi dan misi madrasah, dan diterjemahkan dalam berbagai

\footnotetext{
13 Imam Gunawan, Metode Penelitian Kualitatif: Teori Dan Praktik (Jakarta: Bumi Aksara, 2013), 116.

${ }^{14}$ Matthew B. Miles, A. Michael Huberman, and Johnny Saldafia, Qualitative Data Analysis a Methods Sourcebook (USA: Sage Publication Inc, 2014), 12.
} 
program kegiatan pendidikan dan pembelajaran. ${ }^{15}$

Berdasarkan data dokumentasi bahwa visi pondok pesantren Al-Qodiri Jember didasarkan pada pemikiran $\mathrm{KH}$ Muzakki Syah. Pemikiran beliau terpengaruh dan terilhami oleh dua nilai urgen: pertama pemikiran beliau disandarkan pada keyakinan bahwa asma Allah yakni "Al- Qaadir" (Dzat yang maha kuasa diatas segalanya) menjadi benteng keyakinan bagi seluruh stakeholder yang ada di pondok pesantren yang memiliki beragam lembaga ini. Kedua, pemikiran beliau juga disandarkan kepada kewalian Syaikh Abdul Qodir Jailani, sehingga beliau mengamalkan Dzikir Manaqib Syaikh Abdul Qodir Jailani sejak beliau masih duduk dibangku sekolah dasar. Penyandaran ini pun tujuan dan doanya agar seluruh stakeholder yang ada di lembaga ini selalu mendapatkan keberkahaan dari karamahnya Syaikh Abdul Qodir Jailani. ${ }^{16}$

Waka kurikulum menambahkan bahwa:

Satu titik tekan dalam visi misi tersebut adalah kandungan nilainilai keunggulan meliputi kekuatan iman, taqwa, aqidah islamiyah, ibadah amaliah (syariah), akhlaq (budi pekerti), penguasaan dan pengamalan Ilmu (iptek dan imtaq), penguasaan bahasa dan kitab, keseimbangan kecerdasan, kematangan kepribadian diri, kompeten dan berprestasi. ${ }^{17}$

\footnotetext{
15 "Wawancara Bersama Wakil Kepala MTs Unggulan Al-Qodiri 1 Jember, Tanggal 1 November," 2018.

${ }^{16}$ Hepni, Mutiara di Tengah Samudra; Biografi KH. Ach. Muzakki Syah (Dokumen, 2007), 38-51. 17 "Wawancara Bersama Waka Kurikulum MTs Unggulan Al-Qodiri 1 Jember, Tanggal 1 November," 2018.
}

Secara teknik, bahwa pemetaan kurikulum di MTs Unggulan al-Qodiri 1 Jember ini sebagaimana dijelaskan oleh Waka kurikulum beriku ini:

Pemetaan kebutuhan kurikulum dimadrasah ini dapat dilihat dari apa kebutuhan dasar madrasah ini berdiri? bagaimana tujuan berdirinya? program layanan apa yang akan diberikan? bagaimana harapan dari para pembelajar? Madrasah kami berusaha memulai dari pertanyaan-pertanyaan itu. Disamping itu pula dalam merumuskan kebutuhan kurikulum memperhatikan situasi siapa sasaran dari kurikulum, keragaman kemampuan pembelajar, tujuan dan harapannya, kesesuaiain kompetensi pengajarnya, kendala apakah yang muncul dalam pembelajaran, tes dan penilaian apa yang diperlukan, peran apa yang dapat mendukung, keterampilan peserta didik, Tingkat kemahiran apa yang dikehendaki. ${ }^{18}$

Pada perumusan kurikulum di MTs Unggulan Al-Qodiri 1 Jember, selaras dengan pendapat Umar Hamalik, bahwa dalam merumuskan kurikulum memperhatian landasanlandasan yang menjadi pijakan yaitu: landasan religius (agama) yang ditetapkan berdasarkan nilai-nilai Ilahi dalam al-Qur'an dan as-Sunnah. Kedua, landasan filosofis. ${ }^{19}$

\footnotetext{
18 Ibid.

19 Wina Sanjaya, Kurikulum Dan Pembelajaran: Teori Dan Praktik Pengembangan Kurikulum Tingkatan Satuan Pendidikan (KTSP) (Jakarta: Kencana Prenada Media Group, 2008), 43.
} 
Konsep kurikulum di Madrasah unggulan berbasis pesantren secara umum dan ideal menekankan kepada pembentukan karakter peserta didik. Sebagaimana dicanangkan oleh Kementerian Pendidikan dan Kebudayaan bahwa pendidikan karakter harus menjadi identitas pendidikan nasional. Pondok pesantren melalui berbagai unit lembaga pendidikannya berikhtiar membentuk karakter peserta didik, hal ini tampak dari aktivitas pendidikan fullday tanpa mengenal lelah dan waktu, semua aktivitas tercermin membentuk karakter dan kepribadian peserta didik, agar menjadi manusia kamil (sempurna). Berdasarkan hasil wawancara dengan waka kurikulum:

MTs Unggulan Al-Qodiri 1 Jember sebagai lembaga Islamic Boarding School ini pak, telah menerapkan kurikulum dan pembelajaran berbasis karakter sesuai dengan rencana dan ketentuan yang telah ditetapkan. Model kurikulum dan Pembelajaran berbasis karakter di madrasah ini akan menjadikan peserta didik beriman, dan bertaqwa kepada Tuhan Yang Maha Esa. Nilai-nilai karakter juga diintegrasikan dalam aspek kurikulum dan pembelajaran seperti nilai religius, jujur, kedisiplinan dan lainnya, kesemua nilai karakter tersebut, madrasah merumuskan kembali menjadi empat nilai yaitu kedisiplinan, keikhlasan, kesederhanaan, akhlakul karimah.. ${ }^{20}$

\section{Data di atas dikuatkan berdasarkan hasil penelitian yang}

dilakukan oleh Humairo dan Anam tentang integrasi nilai-nilai karakter dalam pembelajaran di Islamic Boarding School, bahwa desain kurikulum yang dilakukan oleh MTs Unggulan Al-Qodiri 1 Jember ini telah menekankan pada pembentukan karakter peserta didik melalui beragam kegiatan dan dokumen seperti pada perencanaan pembelajaran baik itu silabus dan RPP serta aktivitas peserta didik dalam proses pembelajaran. ${ }^{21}$

Data di atas memberikan fakta bahwa desain pemetaan kebutuhan kurikulum di MTs Unggulan Al-Qodiri 1 Jember memiliki karakteristik tersendiri. Targetnya adalah karakter dan kepribadian peserta didik menjadi baik selaras dengan nilai-nilai keunggulan yang menjadi identitas madrasah tersebut. Pemetaan kebutuhan kurikulum di madrasah tersebut berdasarkan kepada filosofi madrasah di bawah naungan pesantren yang memegang teguh prinsip tafaqquh fi addin dan budaya bangsa. Dengan memasukkan nilai karakter yang agamis dan nasionalis maka kurikulum di madrasah tersebut dapat dinilai sebagai kurikulum yang bermutu dan berkualitas.

Sedangkan di MTs Unggulan Nurul Islam 1 Jember, bahwa konsep pemetaan kebutuhan kurikulum, tidak jauh berbeda dengan di MTs Unggulan Al-Qodiri 1 Jember. Di MTs Unggulan Nurul Islam 1 Jember mengacu kepada visi dan misi dasar pondok pesantren dan visi misi MTs unggulan Nurul Islam 1 Jember itu sendiri. Sebagaimana hasil wawancara berikut:

Islamic Boarding School," AL-QODIRI: Jurnal Pendidikan, Sosial dan Keagamaan 13, no. 2 (2013):

1-9, http://ejournal.kopertais4.or.id/tapalkuda/ind ex.php/qodiri/article/view/2927. 
Spirit awal berdirinya lembaga selaras dengan spirit pondok pesantren. spirit keunggulan ini tercermin dalam visinya adalah terbentuknya siswa yang unggul prestasi berdasarkan iman dan taqwa, dengan indikator visinya adalah unggul dalam pembinaan keagamaan Islam berciri khas pesantren (aswaja), unggul dalam peningkatan prestasi UNAS, unggul dalam prestasi bahasa Inggris dan bahasa Arab, unggul dalam penguasaan kitab dan tahfidz, unggul dalam penguasaan sains dan non sains. ${ }^{22}$

Kata-kata unggul disini, memiliki arti kelebihan atau keutamaan. Di MTs Unggulan Nurul Islam 1 Jember kelebihan tersebut dapat dilihat dari aspek manajemen dan kurikulumnya. Yang paling tampak adalah visi dan misi lembaga dan program-program yang ditawarkan dengan 3 kategori program yaitu sains, non sains dan pengembangan bahasa.

Proses pemetaan kebutuhan kurikulum di MTs Unggulan Nurul Islam 1 Jember didasarkan kepada beberapa hal urgen berikut ini:

Memperhatikan dan mengacu pada beberapa hal penting. Diantaranya memahami situasi siapa sasaran kurikulum, siapakah pembelajar, bagaimana tujuan dan harapan dari pembelajar, seperti apa gaya belajar yang disukai, bagaimana kesiapan kompetensi para pengajar, kegiatan pelatihan dan pengalaman apakah yang pernah diikuti dan dimiliki oleh

\footnotetext{
22 "Wawancara Bersama Wakil Kepala MTs Unggulan Nurul Islam 1 Jember, Tanggal 31 Oktober," 2018.
}

\begin{abstract}
para pengajar, pendekatan mengajar apa yang disenangi pengajar, kendala apa saja yang dialami dalam pembelajaran, jenis tes dan penilaian seperti apa yang diperlukan serta memahami pula latar belakang mengapa para pembelajar mempelajari materi tersebut. $^{23}$
\end{abstract}

Proses pemetaan kebutuhan kurikulum yang dilakukan kedua madrasah unggulan merupakan sebuah langkah konkrit melakukan inovasi dalam konteks kurikulum dan ini merupakan bagian dari tiga langkah yang harus terus dilakukan sehingga menjadikan madrasah terus bermutu dan unggul. Dua langkah lainnya yang mesti dilakukan yaitu memanfaatkan teknologi dan merubah pola pikir. ${ }^{24}$

\section{Formulasi Kurikulum di MTs Al- Qodiri Unggulan 1 Jember dan MTs Unggulan Nurul Islam 1 Jember}

Terdapat lima kurikulum yang berorientasi pada keunggulan di MTs Unggulan Al-Qodiri 1 Jember, terdiri dari: program tahfidz, bahasa Inggris dan bahasa arab (lugghotaini), tartil alQur'an, membaca kitab kuning serta pembiasaan/pembudayaan karakter dan akhlak. Kurikulum ini sudah dimulai sejak tahun 2012. Selain program tahfidz, dan sudah berjalan hampir 6 tahun. Kurikulum unggul di madrasah ini lebih ditekankan kepada kejujuran siswa, bila tahap kejujuran ini terlaksana maka semua program unggulan yang direncanakan menjadi berhasil. Jadi kami selaku pengelola madrasah memiliki rasa tanggung jawab untuk menanamkan nilai-nilai

\footnotetext{
23 "Wawancara Bersama Waka Kurikulum MTs Unggulan Nurul Islam 1 Jember, Tanggal 31 Oktober," 2018.

24 Mujtahid, "Pengembangan Madrasah Dan Sekolah Islam Unggulan."
} 
jujur dalam setiap program yang kami unggulkan. ${ }^{25}$

Lima program unggulan ini menjadi lima jaminan kompetensi di madrasah ini, namun secara latar belakang alasan memilih lima program unggulan ini adalah karena merupakan ciri khas pesantren seperti program dua bahasa dan membaca kitab kuning, selanjutnya bahasa Inggris dan program tahfidz dipilih karena merupakan tuntutan masyarakat saat ini, sedangkan program tartil al-Qur'an menjadi landasan dasar semua jaminan kompetensi.

Dua alasan lainnya, mengapa ada ide untuk menerapkan program unggulan di MTs Unggulan al-Qodiri 1 Jember, pertama, karena melihat fenomena di masyarakat akan minimnya nilai- nilai pesantren yang terlihat dan muncul dari para santri alumni pondok pesantren. Fenomena ini memberikan landasan akan munculnya ide untuk menerapkan kurikulum pesantren yang unggul dan dapat dilihat langsung oleh masyarakat hasilnya (alumninya). Kedua, faktor kedisiplinan, masalah disiplin ini memang ditekankan karena merupakan bagian dari pada unggul dalam konteks kurikulum madrasah.

Sedangkan di MTs Unggulan Nurul Islam 1 Jember, untuk menjaga kualitas kurikulum, setiap lembaga satuan pendidikan melakukan proses formulasi secara berkelanjutan terhadap indikator ketercapaian kurikulumnya. Hal ini bisa dilihat dari indikator rencana pembelajaran yang tertuang dalam silabus dan RPP nya serta ketercapaian kriteria ketuntasan

25 "Wawancara Bersama Waka Kesiswaan MTs Unggulan Al-Qodiri 1 Jember, Tanggal 6 Desember," 2018.

26 Farida Hanun, "Evaluasi Penyelenggaran Madrasah Unggulan: Studi Kasus Di Madrasah minimum hasil dari proses belajarnya. Hal itu telah diatur dialam peraturan perundang-undangan. Di samping itu pula formulasi dalam program ekstrakurikulernya sebagai bentuk penguatan pembinaan agar dapat mensupport ketercapaian kualitas belajarnya.

Aspek mutu di bidang pendidikan, yayasan Pondok Pesantren memiliki seksi atau lembaga penjamin mutu yang membentuk pengurus di bidang pendidikan formal dan seksi sumber daya manusia. Lembaga ini tugasnya ialah memantau dan memberikan masukan serta membina dan mendiklat guru di lingkungan yayasan pondok pesantren. Seksi atau lembaga ini menjadi bagian atau indikator mutu sebuah lembaga pendidikan, sebagaimana yang disampaikan oleh Nanang Fattah bahwa ada 6 indikator madrasah bisa disebut dan dinilai sebagai madrasah unggul, satu dari enam indikator tersebut ialah adanya kendali mutu yang berkelanjutan atau quality control. ${ }^{26}$

Ikhtiar yang telah dilakukan MTs Unggulan Al-Qodiri 1 Jember dan MTs Unggulan Nurul Islam 1 Jember dengan melakukan formulasi kurikulumnya baik intrakurikuler dan ekstrakurikuler tanpa meninggalkan prinsip pondok pesantren yang ditanamkan oleh pihak pengasuh dapat dikuatkan oleh pandangan Philip Crosby, Edward Deming dan Joseph Juran tentang konsep peningkatan mutu (Total Quality Manajemen), bahwa untuk meraih kualitas diperlukan setidaknya 5 hal urgen sebagai berikut: pertama, komitmen diperlukan dan tertanam

Ibtidaiyah Negeri (MIN) Serawi Kalimantan Selatan," Dialog: Jurnal Penelitian dan Kajian Keagamaan 40, no. 1 (2017): 35-46. 
kepada setiap orang, karena kualitas merupakan kunci keberhasilan. Kedua, bahwa perbaikan kualitas menuntut komitmen manajemen sepenuhnya. Ketiga, untuk memperbaiki kualitas memerlukan kerja keras terutama pada aspek budaya mutu organisasi. Keempat, memperbaiki kualitas memerlukan pembinaan/ pelatihan. Kelima, memperbaiki kualitas menuntut keterlibatan total karyawan yang secara aktif, dan berkomitmen mutlak dari manajemen dara pada senior yang telah berpengalaman sebelumnya. ${ }^{27}$

Berdasarkan data di atas dapat dinyatakan bahwa madrasah unggulan yang telah menjadi identitas seperti MTs Unggulan Al-Qodiri 1 Jember dan MTs Unggulan Nurul Islam 1 Jember adalah cerminan sekolah/madrasah unggulan yang berada di bawah naungan pesantren dan keberadaan dan kehadirannya sangat diharapkan oleh masyarakat untuk selalu konsisten di dalam menjaga kualitasnya secara terus menerus, dan tidak siap bersaing dengan lembaga pendidikan unggulan di luar pesantren. Ini menjadi kekuatan baru pesantren untuk merespon tantangan-tantangan nyata kedepan terlebih menyiapkan generasi serta lulusan yang berkualitas dan bermutu.

\section{Kebijakan Operasionalisasi Kurikulum di MTs Al-Qodiri Unggulan 1 Jember dan MTs Unggulan Nurul Islam 1 Jember}

Kebijakan operasionalisasi kurikulum di MTs Unggulan Al-Qodiri 1 Jember tetap harus melalui persetujuan pengasuh pondok pesantren, namun kepala madrasah yang menyampaikan kurikulum tersebut dalam forum

27 Edward, Total Quality Management In Education, 25. musyawarah. Sebagaimana hasil wawancara berikut ini:

Bagi MTs Unggulan Al-Qodiri 1 Jember sebagai unit lembaga pendidikan di bawah naungan pondok pesantren, peran kepala madrasah dapat membantu untuk mengkomunikasikan rencana yang telah menjadi keputusan bersama dari hasil forum rapat. Disamping itu, juga dapat membantu untuk meyakinkan kepada pihak yayasan agar program unggulan yang dicanangkan dapat diterapkan dalam sistem integrasi antara kurikulum sekolah dengan kurikulum pesantren atau diniyah. Kepala sekolah yang mengusulkan kepada pimpinan pesantren dalam hal ini pimpinan yayasan agar kurikulum unggulan ini dapat diterima dan dilaksanakan di MTs Unggulan al-Qodiri 1 Jember. ${ }^{28}$

Kebijakan operasionalisasi mutu kurikulum, bersandar pada Peraturan Pemerintah Nomor 19 Tahun 2005, tentang standar nasional pendidikan dan peraturan Menteri Pendidikan Nasional Republik Indonesia Nomor 41 tahun 2007, tentang standar proses. Dalam pelaksanaannya, ada tim pemantau yang bertugas memantau kebijakan program kurikulum di MTs Unggulan Al-Qodiri 1 Jember. Sebagai bentuk pertanggungjawaban, maka setiap tahun melaporkan berbagai kegiatan kepada pemerintah melalui kegiatan evaluasi diri madrasah untuk menjamin adanya timbal balik kepada pemerintah sebagai mana amanah undang-undang, melalui EDM tersebut nantinya akan dipotret secara keseluruhan kualitas berbagai kegiatan.

28 "Wawancara Bersama Waka Kurikulum MTs Unggulan Al-Qodiri 1 Jember, Tanggal 1 November." 
Sedangkan di MTs Unggulan Nurul Islam 1 Jember, sebagai lembaga pendidikan yang bernaung di bawah pondok pesantren, memiliki tanggung jawab dalam menerjemahkan visi, misi, tujuan, baik pondok pesantren maupun madrasahnya dalam bentuk kebijakan, baik secara tertulis maupun tidak. Meskipun secara kultur, lembaga pendidikan sebagai unit yang bernaung di bawah kendali pondok pesantren, namun memiliki budaya organisasi yang berbeda tetapi tetap menghormati dan memperjuangkan visi pesantren (tidak bertentangan sepenuhnya). Contohnya soal pengaturan jadwal pendidikan, antara program pesantren dengan program sekolah, dapat dirumuskan bersama agar berjalan secara sinergis dan tidak berbenturan satu sama lain.

Berkaitan dengan itu, struktur kaitannya dengan keputusan-keputusan di setiap unit/bagian, bersama-sama mengajukan usulan dan masukan kepada pimpinan organisasi terkait dengan langkah yang diambil bersama dalam wujud program kerja. Program kerja bisa berdurasi jangka pendek, menengah maupun panjang. Oleh sebab itu, kebijakan dalam bentuk program kerja merupakan manifestasi dari rencana strategis yang telah diagendakan bersama. Sebagaimana hasil wawancara berikut:

MTs unggulan Nurul Islam 1 Jember dalam menetapkan kebijakannya sehingga berwujud program kerja telah dipetakan berdasarkan bidang masingmasing. Setiap bidang memiliki program kerja tersendiri, sesuai dengan target, sasaran dan tujuan. Dalam bidang kurikulum

\footnotetext{
29 "Wawancara Bersama Wakil Kepala MTs Unggulan Nurul Islam 1 Jember, Tanggal 31 Oktober."
}

khususnya telah dirumuskan program kerja. Bidang-bidang itu telah merumuskan program kerjanya, ada yang harian, mingguan, bulanan dan tahunan. Secara umum telah terjabarkan dalam pedoman kerja kepala madrasah yang didalamnya juga tertuang program kerja bidang masing-masing. Semua program kerja telah direncanakan dengan baik dan melalui proses musyawarah mufakat dan hasilnya disampaikan kepada yayasan, harapannya dapat menjadi bahan pertimbangan dan laporan. ${ }^{29}$

Kebijakan operasionalisasi kurikulum yang telah dilakukan kedua madrasah unggul tersebut merupakan bentuk nyata bahwa madrasah unggul sudah mulai banyak diminati oleh masyarakat secara luas karena beragam keunggulan yang telah diberikan terutama dalam konteks kurikulumnya. Maka itu Farid Hasyim menyatakan bahwa ada tiga syarat agar madrasah dapat selalu menjadi unggul, ketiga syarat tersebut ialah: lingkungan kelas yang selalu kondusif untuk proses pembelajaran, pembelajaran memiliki sistem yang terukur atau bermutu, dan selalu berbasis teknologi. ${ }^{30}$

Berdasarkan data di atas, bahwa kebijakan yang telah tertuang dalam program kerja, merupakan bukti nyata, bahwa madrasah yang berkategori unggul, ditandai dengan adanya spirit untuk meningkatkan kualitas kurikulumnya dengan mengimplementasikan kebijakan yang berbentuk program dan di gagas secara

30 A. Zuhdi, "Madrasah Sebagai Tipologi Lembaga Pendidikan Islam (Kajian Tentang Berbagai Model Madrasah Unggulan)," Madrasah 5, no. 1 (2013): 1-8. 
terstruktur, fokus, dan adanya ikhtiar memantau secara berkelanjutan, mulai dari aspek input, proses, output serta outcome-nya, lulusan terbaik akan terwujud jika program-program yang ada, khususnya pada aspek kurikulum mampu diformulasi secara terus menerus dengan target dan sasaran yang jelas dan terukur dengan durasi waktu tertentu berdasarkan pedoman atau instrumen yang tepat pula, disertai dengan komitmen yang sungguhsungguh, maka keberhasilan kurikulum akan tampak dan dirasakan, tidak hanya para pengelola namun lebih-lebih masyarakat sebagai pengguna lulusan.

\section{KESIMPULAN}

Berdasarkan hasil penyajian dan analisa data penelitian, dapat disimpulkan sebagai berikut : Pertama, konsep pemetaan kebutuhan kurikulum di MTs Unggulan Al-Qodiri 1 Jember dan MTs Unggulan Nurul Islam 1 Jember mendasarkan kepada visi, misi dan tujuan pondok pesantren dan madrasah.

Kedua, Formulasi kurikulum di MTs Unggulan Al-Qodiri 1 Jember ini dapat terlihat dari lima program yang telah dilakukan seperti program tahfidz, bahasa Arab dan bahasa Inggris (lugghotaini), tartil al-Qur'an, membaca kitab kuning dan pembudayaan karakter atau akhlak. Sedangkan di MTs Unggulan Nurul Islam 1 Jember dilakukan dengan tujuan untuk menjaga kualitas pembelajaran, selain itu, formulasi juga dilakukan pada program ekstrakurikulernya sebagai bentuk penguatan pembinaan agar dapat menssuport ketercapaian kualitas belajarnya.

Ketiga, kebijakan operasionalisasi mutu kurikulum di MTs Unggulan AlQodiri 1 Jember dipantau dari laporan evaluasi diri madrasah setiap akhir tahun pelajaran. Sedangkan di MTs Nurul Islam 1 Jember kebijakannya dalam bentuk program kerja baik itu mingguan, bulanan, maupun tahunan. Program kerja telah dimusyawarahkan dan disampaikan kepada pihak yayasan untuk menjadi pertimbangan sekaligus sebagai bentuk laporan.

\section{REFERENSI}

Edward, Sallis. Total Quality Management In Education. Edited by AHmad Ali Riyadi. Jogjakarta: IRCiSoD, 2008.

Fachruddin, Fuad. "Madrasah Model: Indikator Obyektif Dan Operasionalnya." Jurnal Madrasah 3 (1998): 80.

Gunawan, Imam. Metode Penelitian Kualitatif: Teori Dan Praktik. Jakarta: Bumi Aksara, 2013.

Hanun, Farida. "Evaluasi Penyelenggaran Madrasah Unggulan: Studi Kasus Di Madrasah Ibtidaiyah Negeri (MIN) Serawi Kalimantan Selatan." Dialog: Jurnal Penelitian dan Kajian Keagamaan 40, no. 1 (2017): 35-46.

Hepni, Mutiara Di Tengah Samudra; Biografi KH. Ach. Muzakki Syah. Dokumen, 2007.

Khumairo, Dewi, and Nurul Anam. "Integrasi Nilai-Nilai Karakter Dalam Pembelajaran Di Islamic Boarding School." AL-QODIRI: Jurnal Pendidikan, Sosial dan Keagamaan 13, no. 2 (2013): 1-9. http://ejournal.kopertais4.or.id/ta palkuda/index.php/qodiri/article/ view/2927.

Marno. Islam: By Management and Leadership. Jakarta: Lintas Pustaka, 2007.

Miles, Matthew B., A. Michael Huberman, and Johnny Saldafia. 
Qualitative Data Analysis a Methods Sourcebook. USA: Sage Publication Inc, 2014.

Moedjiarto. Sekolah Unggul. Surabaya: Duta Graha Pustaka, 2002.

Moleong, Lexy J. Metodologi Penelitian Kualitatif. Bandung: Remaja Rosdakarya, 2005.

Mujtahid. "Pengembangan Madrasah Dan Sekolah Islam Unggulan." Jurnal el-Hikmah: Fakultas Tarbiyah UIN Malang IX, no. 1 (2011): 274-289.

Sanjaya, Wina. Kurikulum Dan Pembelajaran: Teori Dan Praktik Pengembangan Kurikulum Tingkatan Satuan Pendidikan (KTSP). Jakarta: Kencana Prenada Media Group, 2008.

Siswanto, Siswanto. "Desain Mutu Pendidikan Pesantren." KARSA: Jurnal Sosial dan Budaya Keislaman 23, no. 2 (2016): 259.

SK Kakanwil Yogyakarta. "Lampiran Surat Keputusan Kepala Kantor Wilayah Kementerian Agama Provinsi Daerah Istimewa Yogyakarta No. 609B Tahun 2012 Tentang Rintisan Madrasah Unggulan, Petunjuk Teknis Penyelenggaraan Ratusan Madrasah Unggulan," 2012.

Subhan, Fa'uti. Membangun Sekolah Unggulan Dalam Sistem Pesantren. Surabaya: Alpha, 2006.

Zayadi, Ahmad. Desain Pengembangan Madrasah. Jakarta: Dirjen Kelembagaan Pendidikan Islam Depag, 2005.

Zuhdi, A. "Madrasah Sebagai Tipologi Lembaga Pendidikan Islam (Kajian Tentang Berbagai Model Madrasah Unggulan)." Madrasah 5, no. 1 (2013): 1-8.
"Peraturan Pemerintah Nomor 19 Tahun 2005 Tentang Standar Nasional Pendidikan," 2005.

"Wawancara Bersama Waka Kesiswaan MTs Unggulan Al-Qodiri 1 Jember, Tanggal 6 Desember," 2018.

"Wawancara Bersama Waka Kurikulum MTs Unggulan Al-Qodiri 1 Jember, Tanggal 1 November," 2018.

"Wawancara Bersama Waka Kurikulum MTs Unggulan Nurul Islam 1 Jember, Tanggal 31 Oktober," 2018.

"Wawancara Bersama Wakil Kepala MTs Unggulan Al-Qodiri 1 Jember, Tanggal 1 November," 2018.

"Wawancara Bersama Wakil Kepala MTs Unggulan Nurul Islam 1 Jember, Tanggal 31 Oktober," 2018. 